Aderopo Raphael Adediyan

(iD) https://orcid.org/0000-0001-5875-0021

Economics Department

Faculty of Social Sciences

University of Benin, Benin City, Nigeria

adediyan@yahoo.com
Oseremen ThankGod Ehisuoria

iD https://orcid.org/0000-0001-9059-3943

Economics Department

Faculty of Social Sciences

University of Benin, Benin City, Nigeria

ehisuoriathankgod1@gmail.com

\title{
External aid behavior in the recipient economy: A probit regression for Africa
}

Accepted by Editor Ewa Ziemba | Received: January 19, 2021 | Revised: May 28, 2021; December 12, 2021; January 9, 2022 | Accepted: January 12, 2022 | Published: January 27, 2022.

(C) 2022 Author(s). This article is licensed under the Creative Commons Attribution-NonCommercial 4.0 license (https://creativecommons.org/licenses/by-nc/4.0/)

\begin{abstract}
Aim/purpose - External aid allocation by the donors in recent years has been fraught with instability and volatility. This has a negative consequence on the recipient economies particularly those that are highly aid-dependent. A good solution to the problem requires much understanding of factors influencing the behavior of external aid in the respective recipient economy. In this study, the focus was on analyzing two economic factors uncommonly discussed in the empirical literature - the influence of the degree of economic freedom and external debt burden on aid allocation, with emphasis on African economy.
\end{abstract}

Design/methodology/approach - The study constructs a probit model for the analysis using a panel dataset consisting of 48 African countries from 2010 to 2019.

Findings - The key findings of the study include a significant positive effect of economic freedom on aid and it implies that the probability of an additional external aid allocation to African countries increases with an increase in the degree of economic freedom. However, external debt burden, albeit positive, is not statistically significant to motivate more external aid allocations to Africa over the sample period.

Research implications/limitations - Hence, the pattern of external aid inflows in Africa is a reflection of a change in the degree of economic freedom in the region.

Originality/value/contribution - In contribution to filling the gap in the literature on external aid inflow in the recipient economies, the study traced external aid fluctuations in Africa to external debt burden and the extent of restriction imposed on economic freedom in African countries.

Cite as: Adediyan, A. R., \& Ehisuoria, O. T. (2022). External aid behavior in the recipient economy: A probit regression for Africa. Journal of Economics \& Management, 44, 1-18.

https://doi.org/10.22367/jem.2022.44.01 
Keywords: external aid, economic freedom, external debt burden, probit regression. JEL Classification: F34, F35, C01, E02.

\section{Introduction}

A large number of countries in developing countries continue to put in efforts to draw home external aid to meet the socioeconomic, political, cultural, and institutional needs of the economy (Rena, 2013). But a challenge remains as to whether external aid adequately fits in enough to help achieve the development objective of these countries. Several studies, such as Easterly (2003), Liu, Fan, Chao, and Yu (2019), Adediyan and Obadoni (2020), Burnside and Dollar (2000), Asongu (2014), Kaya, Kaya, and Gunter (2012), Appiah-Konadu, Junior, Eric, and Twerefou (2016), Dalgaard and Hansen (2001), Kaya and Kaya (2020), and Clemens, Radelet, Bhavnani, and Bazzi (2012), have attempted to shed light on the potential impacts of external aid on economic growth and development but the conclusion differs. While the rationale for the disparity is beyond this paper, the focus is on providing a concise explanation of external aid behavior over time in the recipient economies. Here, two important categories of economic related factors come to mind: the supply and the demand side factors (Appiah-Konadu et al., 2016; Park, 2019). That is, factors relating to the motive of the donor countries or agencies and that of the recipient economies. Many donors often allocate aid on a basis of the effectiveness of the previous amount disbursed (Park, 2019). In countries where more achievement is evident more aid disbursement is made by the donors compared to others with no tangible realizations from the aid received. Typically, external aid is given to tackle socioeconomic problems like poverty, epidemics (such as malaria, HIV/AIDS, COVID-19, and Tuberculosis), conflicts, malnutrition, famine, societal disorder, debt overhang and poor education and health system.

In the spirit of Rena (2013) and Tseggai (2006), however, if external aid is provided to redress such problems, its impact in the developing countries is meaningless and has not achieved its goals. Technically, it means that aid allocation is expected to be generally low in several developing countries since in most cases the realized targets or objectives of the donors lagged behind expectation. In another dimension, the political and trade allies of aid donors also explain why external aid varies from region to region and even within a particular region or country. For example, Jayathilaka and Bandara (2009) stressed that external aid provided by Japan usually flows more to the countries where Japan has much 
trading interest or where aid is tied to the purchase of Japanese products in return for the aid provided. In this way, external aid will be more, says, in the period of a high trading interest and less when trading interest is shifted from the country. A good number of aid donor countries preferred providing a tied or "condition-based" aid to the benefiting economies owing to self-interest or expected gain which makes external aid vary disproportionally over time or region. Alesina and Dollar (2000) added that a lot of aid donors provide a considerable amount of external aid to their former colonies to retain dominance.

Nonetheless, much concern here is on the demand side which essentially centered on factors relating to the pattern of external aid in the recipient economy. For aid recipient economies, crucial factors determining the level of external aid that come into the economy include the size of government consumption, poverty, the degree of economic integration with global economy, epidemics, market size, population, and the level of economic freedom and macroeconomic policy coordination or management. This paper takes up two of these factors, namely: the degree of economic freedom and external debt burden, which are less emphasized on in the past studies but closely linked to the external aid inflows. For example, in the case of external debt burden, given the level of the structural weakness of the economy of the developing countries, a high external debt service ratio makes countries extremely at risk of a mounting pressure on the balance of payment which could hamper economic growth and development. It is also well said that heavy debt stock repayment and debt service payment often lead to a "crowding-out effect" and therefore reduce domestic investment, increase poverty, and deter economic development (Iyoha, 2004).

As a result, many aid donors are committed to allocating a substantial amount of external aid to regions or countries battling with a high debt burden profile to offset its negative impacts. The World Bank, IMF and Paris Club are typical aid donors that have extended more aid to high debt-burdened countries often through debt cancellation or forgiveness - debt relief. A case in point is the approval of $\$ 500$ million by the IMF on April 14, 2020 to cancel six months of debt repayment for 25 economies, 19 of which were in the region of Africa (Sun, 2020). Yet, other aid donors like Japan and South Korea may not give aid conditioned on the debt profile of the aid receiving economies but mainly on trade relations (Jayathilaka \& Bandara, 2009). Therefore, on average, can the level of external debt burden determine the total amount of external aid granted by the donors? Does external aid inflow into the aid recipient countries increase with a high external debt burden? The same extend to economic freedom factor. Take 
for instance, where the target of the donor is to tie the recipient economy to the donor's economy, maintain a colonial tie or sustain imperialism, such a donor is unlikely to provide more aid to the economy with a high degree of freedom, and vice-versa. Contrarily, donor agencies favoring free market fundamentalism will be willing to grant more aid to a country with a high degree of freedom than those with less. It is, however, true that this may not hold at all time owing to a possible change in the donor's objectives and targets over time.

The broad aim of this paper is on predicting the probability of economic freedom and external debt burden determining the level of external aid inflow in the recipient economies with focus on Africa. While reports by the Fraser Institute put Africa at the bottom of the global economic freedom, data from the World Bank suggest that Africa's economy is one of the most difficult economies for starting up or doing business. Similarly, the debt profile of Africa for decades has been one of the worse globally (Sun, 2020). Altogether, these two scenarios supposedly put Africa in the position of getting more aid than any other continents with little of these characteristics.

The rest of this paper is divided into the following sections. Section 2 highlights economic review, Section 3 presents the study's methodology, Section 4 is on finding presentations and result discussion, and section 5 is the conclusion of the study.

\section{Literature review}

One of the challenges in the literature on external aid is the lack of a correct and adequate analytical construction or framework to explain the mechanism of work, structure and the determinants of external aid. Lots of researchers have attempted to overcome the problem by explaining why donors give aid and why the recipients agree to take it from the donors (e.g., Ali, Banks, \& Parsons, 2015; Appiah-Konadu et al., 2016; Park, 2019). The latter is much on economic ground and is deeply rooted in the dependency theory of economic development where external aid is believed to have a crucial role in the process of economic development. Underpinning the dependency model is the view that the developing or aid recipient economies are plagued by political, institutional and economic rigidities, and therefore, need external assistance from rich economies (Todaro \& Smith, 2014). Rena (2013) and United Nations (2006) argued that many developing countries believe that external aid will help to transform economy structurally and contributes to the overall economic performance, and there- 
fore, agree to accept it. The "East Asian miracle" economies, especially Taiwan Province of China and the Republic of Korea, documented success stories in their early period of economic development owing to large external aid received (Todaro \& Smith, 2014). However, this is not without some exceptions as pointed out by Moyo (2009) that external aid hurts rather than causes economic prosperity. Reference could also be made for the two-gap model where external aid is assumed to be an abridger between local saving and investment gap, and foreign exchange gap, and the Big-Push model which emphasizes a good aid-driven investment to free the poor or developing countries from poverty. Yet related model is the "recipient need" model which pinned down the purpose of external aid allocation to humanitarian needs. That is, external aid is provided to the underdeveloped economies based on humanitarian need without the interference of the donors' interest (Appiah-Konadu et al., 2016). In contrary, the "donor interest model" argued that external aid is allocated to countries with military, trade, and political alliance with the donor countries. While these models are fairly suitable for the explanations of the rational for aid provision by the donors or acceptance of external aid by the recipient countries, understanding the determinants of external aid from the theoretical point of view is still much a challenge. Even so, studies have been done on the potential demand and supply side factors determining aid allocations using both cross-country and country-specific dataset.

In terms of cross-country evidence, Ali and Isse (2006) employed a panel method to study the determinants of external aid in 151 countries between 1975 and 1998. The study argued that taxes on international trade, government consumption and ethnicity positively determine external aid. However, external trade, years of schooling, private credit, GDP per worker have a negative effect on external aid. Furuoka (2017) examined the determinants of Japan's and China's external aid allocations in Africa using pooled and fixed effect approach. The study found that the donors' allocations are more influenced by the donors' interest, population size, quality of governance and institution in African countries. Kim and Oh (2012) investigated the determinants of external aid with reference to South Korea's ODA. The study employed panel data between 1987 and 2009 for 154 aid recipients' countries. The study considered whether the South Korea's ODA reflects the recipient's humanitarian needs than the interest of the donor. The study suggested that South Korea provides more aid to high-income developing countries with a high growth rate which implies that the South Korea aid provided is meant to meet the economic interest of the donor. 
Zengin and Korkmaz (2019) examined the Turkish foreign aid behavior between 2005 and 2016 for 100 Turkish external aid recipients. A system GMM approach was used. In the results, Turkish foreign aid is high in the recipient economy with low per capita income. Furthermore, aid recipient countries having aid relationship with members of the OECD-DAC receive more aid from Turkey. Additionally, aid recipients that are classified as The Turkic Republics get more Turkish aid. For country-specific studies, Uzonyi and Rider (2017) examined the determinants of external aid with focus on domestic instability and rivalry, and how uncertainty emanating from the duo may influence aid transfer among states. The study argued that rival countries may grant aid to one another if one of the countries is exposed to a regime-threatening level of a domestic instability. Rival countries are likely to grant aid to their opponent during uncertainty compared to the non-rivals. Moreover, the study of Zhang (2004) found that humanitarian needs or donors economic interest significantly determine the World Bank provincial loan allocation during the China's era of reform. The study concluded that the interests of the provincial bureaucrats and preferences for central leadership are what matter. Flink and Radaelli (2009) analyzed the supply side determinants of emergency aid and found that donor countries favor closed by small geographical and oil exporting countries and shown bias towards political less aligned countries. The study of Eregha (2009) in Nigeria found that income per capita, population size, domestic savings, and total debt service positively determine aid allocation.

\section{Research methodology}

To achieve its objective, the study constructs a probabilistic model and tests a hypothesis on the likelihood that the degree of economic freedom and external debt burden influence the behavior of external aid in African countries. An expanded linear empirical model of the study's objective function is:

$$
D_{i t}=\omega+\beta E_{i t}+\theta E X D_{i t}+\varphi \boldsymbol{X}_{i t}+\epsilon_{i t}
$$

In equation (1), $D_{i t}$ is a measure of the behavior of external aid at time $t$ for country $i$. It is a dichotomous dummy variable, bounded by a value range between 0 and 1; 1 for a high level of external aid and 0 for a low level. The external aid mean value is used as a threshold above which external aid at time $t$ for country $i$ is declared high or low if it lies below. $E_{i t}$ means economic freedom for country $i$ at time $t$. EXD $D_{i t}$ represents external debt burden. Both eco- 
nomic freedom and external debt burden are the primary explanatory variables in the model and are expected to be positive. $\boldsymbol{X}_{i t}$ represents a vector of auxiliary explanatory variables for country $i$ at time $t$. Variables in $\boldsymbol{X}$ include a dummy measure of conflict and income group to control for heterogeneity in the model. High income countries, like Mauritius, are less dependent on external aid compared to a low income country such as Ethiopia. In addition, countries experiencing conflict are likely to attract more external aid than the non-conflict countries. $\omega, \beta, \theta$ and $\varphi$ are the parameters and the disturbance term is denoted as $\epsilon_{i t}$. To estimate equation (1), a probit model is adopted. It is a binary probabilistic model constraining the value of the dependent variable to 0 and 1 . It is 1 if the event occurs and 0 otherwise. To illustrate the model, presuppose that the probability of external aid is high or low for country $i$ at time $t$ is a function of an unobserved factor $h_{i t}$ which is determined by observable factors, says, $E_{i t}, E X D_{i t}$ and $\boldsymbol{X}_{i t}$ such that:

$$
h_{i t}=\omega+\beta E_{i t}+\theta E X D_{i t}+\varphi \boldsymbol{X}_{i t}
$$

Where $E_{i t}, E X D_{i t}$ and $\boldsymbol{X}_{i t}$ are as earlier described. Following Asteriou and Hall (2011), a probit model based on a cumulative normal distribution function is specified as:

$$
F\left(h_{i t}\right)=\frac{1}{\sqrt{2 \pi}} \int_{-\infty}^{h_{i t}} e^{-h / 2 d h}, \quad P_{i t}=F\left(h_{i t}\right)
$$

Where, in equation (3), $P_{i t}$ refers to the probability that external aid inflow in country $i$ at time $t$ is high; that is, the probability that the dependent ble $D_{i t}=1$, and $h_{i t}$ as defined in equation (2). $F\left(h_{i t}\right)$ is equal to the standard normal cumulative distribution function. If $h_{i t}$ is defined as the inverse of the normal cumulative distribution function, then, a probit model of the study is as in equation (4):

$$
h_{i t}=F^{-1}\left(P_{i t}\right)=\omega+\beta E_{i t}+\theta E X D_{i t}+\varphi \boldsymbol{X}_{i t}
$$

An econometric specification of equation (4) is highlighted as equation (5);

$$
h_{i t}=F^{-1}\left(P_{i t}\right)=\omega+\beta E_{i t}+\theta E X D_{i t}+\varphi \boldsymbol{X}_{i t}+\epsilon_{i t}
$$

Note that some external aid donors especially Ireland, Denmark and Norway noticeably give a large proportion of their aid to the recipients on the basis of regional needs. Hence, adjusting equation (5) to account for the regional effect yields equation (6):

$$
h_{i t}=F^{-1}\left(P_{i t}\right)=\omega+\beta E_{i t}+\theta E X D_{i t}+\varphi \boldsymbol{X}_{i t}+\vartheta \boldsymbol{\Pi}_{i t}+\epsilon_{i t}
$$


In equation (6), $\boldsymbol{\Pi}$ is a vector of dummy variables used to capture the regional effect in the model. $\vartheta$ is the parameter of the regional dummy variables. Note that the middle Africa region is used as a comparison region. Other variables and parameters are as earlier defined.

Furthermore, to account for the period effect in the model, equation (6) is re-specified as follows:

$$
h_{i t}=F^{-1}\left(P_{i t}\right)=\omega+\beta E_{i t}+\theta E X D_{i t}+\varphi \boldsymbol{X}_{i t}+\vartheta \boldsymbol{\Pi}_{i t}+\gamma \Omega_{i t}+\epsilon_{i t}
$$

Where $\Omega_{i t}$ a vector of measures of period effect and $x$ is a parameter representing the period effect. The probit model in equation (5), (6), and (7) is estimated using the Maximum-Likelihood method. In general, Wooldridge (2013) has shown that the Maximum-Likelihood Estimator is asymptotically normal, consistent and efficient. It is important to note that for the most part, economic variables follow a normal distribution. This makes a probit model more suitable for the study than the logit and linear probability models. The data for the study, described in Table 1, are collected for 48 countries in Africa between 2010 and 2019. The detailed description and sources of the data are in Table 1.

Table 1. Data description and sources

\begin{tabular}{|c|c|c|c|c|c|c|}
\hline Variable & Description & Source & mean & $\min$ & $\max$ & SD \\
\hline 1 & 2 & 3 & 4 & 5 & 6 & 7 \\
\hline $\begin{array}{l}\text { Economic } \\
\text { Freedom (E) }\end{array}$ & $\begin{array}{l}\text { Heritage Foundation described economic freedom as } \\
\text { "the absence of government coercion or constraint on } \\
\text { the production, distribution, or consumption of goods } \\
\text { and services beyond the extent necessary for citizens } \\
\text { to protect and maintain liberty itself" (Heritage } \\
\text { Foundation, 2003, Chapter 5)* It is proxy by the } \\
\text { Fraser World average Economic Freedom Index }\end{array}$ & $\begin{array}{l}\text { Fraser } \\
\text { Institute }\end{array}$ & 6.52 & 0 & 8.11 & 12.94 \\
\hline Dummy (D) & $\begin{array}{l}\text { It is a response variable constructed to measure external } \\
\text { aid behavior using data on Net ODA received } \\
(\% \text { of GNI) }\end{array}$ & $\begin{array}{l}\text { World } \\
\text { Bank }\end{array}$ & 0.43 & 0 & 1 & 0.50 \\
\hline \begin{tabular}{|l|l|} 
External debt \\
burden (EXD)
\end{tabular} & $\begin{array}{l}\text { Measured as a percentage of external debt service } \\
\text { to GNI }\end{array}$ & \begin{tabular}{|l|} 
World \\
Bank
\end{tabular} & 2.52 & 0 & 45.12 & 4.01 \\
\hline $\begin{array}{l}\text { Government } \\
\text { size (GZ) }\end{array}$ & $\begin{array}{l}\text { General government final purchases as a percentage } \\
\text { of GDP }\end{array}$ & $\begin{array}{l}\text { World } \\
\text { Bank }\end{array}$ & 14.58 & 0 & 41.89 & 6.69 \\
\hline $\begin{array}{l}\text { Trade openness } \\
\text { (TPN) }\end{array}$ & $\begin{array}{l}\text { Total trade as a percentage of GDP. It means the extent } \\
\text { to which the external aid recipient economy is opened } \\
\text { to foreign trade }\end{array}$ & $\begin{array}{l}\text { World } \\
\text { Bank }\end{array}$ & 71.30 & 0 & 348.0 & 40.61 \\
\hline \begin{tabular}{|l|} 
Population \\
density (POPD)
\end{tabular} & $\begin{array}{l}\text { It refers to people per square } \mathrm{km} \text { of land area. } \\
\text { It is an index of population intensity }\end{array}$ & \begin{tabular}{|l|} 
World \\
Bank
\end{tabular} & $\mid 100.0$ & 0 & 623.3 & 127.1 \\
\hline \begin{tabular}{|l|} 
Malaria incidence \\
(MI)
\end{tabular} & Incidence of malaria (per 1,000 population at risk) & $\begin{array}{l}\text { World } \\
\text { Bank }\end{array}$ & 176.4 & 0 & 585.5 & 158.1 \\
\hline
\end{tabular}


table 1 cont.

\begin{tabular}{|l|l|l|r|r|r|r|}
\hline \multicolumn{1}{|c|}{1} & \multicolumn{1}{|c|}{2} & \multicolumn{1}{|c|}{3} & \multicolumn{1}{|c|}{4} & \multicolumn{1}{|c|}{5} & \multicolumn{1}{|c|}{7} \\
\hline $\begin{array}{l}\text { Environmental } \\
\text { quality (EQ) }\end{array}$ & $\begin{array}{l}\text { This is proxy by CO2 emissions in kg per PPP US \$ } \\
\text { of GDP }\end{array}$ & $\begin{array}{l}\text { World } \\
\text { Bank }\end{array}$ & 0.16 & 0 & 0.78 & 0.11 \\
\hline Income group & $\begin{array}{l}\text { A dummy construct based on World Bank income } \\
\text { classification of countries }\end{array}$ & $\begin{array}{l}\text { World } \\
\text { Bank }\end{array}$ & 0.02 & 0 & 1 & 0.14 \\
\hline $\begin{array}{l}\text { Age dependency } \\
\text { ratio (ADR) }\end{array}$ & Age dependency ratio (\% of working-age population) & $\begin{array}{l}\text { World } \\
\text { Bank }\end{array}$ & 79.56 & 41.3 & 111.9 & 15.94 \\
\hline Conflict & $\begin{array}{l}\text { A dummy variable used as a measure indicating whether } \\
\text { country } i \text { belongs to a conflict or non-conflict region }\end{array}$ & ACCORD & 0.36 & 0 & 1 & 0.48 \\
\hline $\begin{array}{l}\text { Transparency, } \\
\text { accountability and } \\
\text { corruption (TAC) }\end{array}$ & $\begin{array}{l}\text { CPIA transparency, accountability, and corruption } \\
\text { in the public sector rating }\end{array}$ & $\begin{array}{l}\text { World } \\
\text { Bank }\end{array}$ & 2.17 & 0 & 4.50 & 1.24 \\
\hline
\end{tabular}

* The idea is rooted in Adams Smith's economic philosophy. Detailed in 2003 Index of Economic freedom by Heritage Foundation.

Source: Authors' own elaboration.

\section{Research findings}

The empirical results of the models are presented in Table 2, 3 and 4, respectively. The results in Table 2 and 3 are estimates based on equation (5) model specification. In Table 2, the baseline regression for the study is as in the column 2. Result in column 3 through 9 controls for income class (Y), conflict/stability (CONF), macroeconomic management (MMGT), malaria incidence (MI), environmental quality (EQ), and transparency, accountability and corruption (TAC) contrast to the baseline result highlighted in column 2.

Table 2. Probit regressions on the external aid behavior in Africa

\begin{tabular}{|c|c|c|c|c|c|c|c|}
\hline Variables & (1) & (2) & (3) & (4) & (5) & (6) & (7) \\
\hline 1 & 2 & 3 & 4 & 5 & 6 & 7 & 8 \\
\hline $\mathrm{EF}$ & $\begin{array}{r}0.0064 \\
(0.03)^{* *} \\
\end{array}$ & $\begin{array}{r}0.0060 \\
(0.02)^{* *}\end{array}$ & $\begin{array}{r}0.0067 \\
(0.02)^{* *}\end{array}$ & $\begin{array}{r}0.0070 \\
(0.03)^{* *}\end{array}$ & $\begin{array}{r}0.0064 \\
(0.02)^{* *} \\
\end{array}$ & $\begin{array}{r}0.0066 \\
(0.03)^{* *} \\
\end{array}$ & $\begin{array}{r}0.0067 \\
(0.02)^{* *}\end{array}$ \\
\hline EXD & $\begin{array}{r}0.0045 \\
(0.79) \\
\end{array}$ & $\begin{array}{r}-0.0148 \\
(0.53) \\
\end{array}$ & $\begin{array}{r}0.0054 \\
(0.75) \\
\end{array}$ & $\begin{array}{r}0.0010 \\
(0.95) \\
\end{array}$ & $\begin{array}{r}0.0055 \\
(0.75) \\
\end{array}$ & $\begin{array}{r}0.0019 \\
(0.91) \\
\end{array}$ & $\begin{array}{r}-0.014 \\
(0.57) \\
\end{array}$ \\
\hline GZ & \begin{tabular}{r|}
0.0063 \\
$(0.52)$ \\
\end{tabular} & $\begin{array}{r}0.0066 \\
(0.50) \\
\end{array}$ & $\begin{array}{r}0.0069 \\
(0.48) \\
\end{array}$ & $\begin{array}{r}0.0046 \\
(0.64) \\
\end{array}$ & $\begin{array}{r}0.0076 \\
(0.49) \\
\end{array}$ & \begin{tabular}{r|}
0.0051 \\
$(0.61)$ \\
\end{tabular} & $\begin{array}{r}0.0088 \\
(0.43) \\
\end{array}$ \\
\hline TPN & $\begin{array}{r}-0.0046 \\
(0.01) * \\
\end{array}$ & $\begin{array}{r}-0.0047 \\
(0.01) * \\
\end{array}$ & $\begin{array}{r}-0.0051 \\
(0.00)^{*} \\
\end{array}$ & $\begin{array}{r}-0.0046 \\
(0.01)^{*} \\
\end{array}$ & $\begin{array}{r}-0.0046 \\
(0.01)^{*} \\
\end{array}$ & $\begin{array}{r}-0.0045 \\
(0.01)^{*} \\
\end{array}$ & $\begin{array}{r}-0.0052 \\
(0.01)^{*} \\
\end{array}$ \\
\hline POPD & $\begin{array}{r}-0.0005 \\
(0.32) \\
\end{array}$ & $\begin{array}{r}-0.0009 \\
(0.14) \\
\end{array}$ & $\begin{array}{r}-0.0006 \\
(0.28) \\
\end{array}$ & $\begin{array}{r}-0.0005 \\
(0.32) \\
\end{array}$ & $\begin{array}{r}-0.0005 \\
(0.31) \\
\end{array}$ & $\begin{array}{r}-0.0005 \\
(0.37) \\
\end{array}$ & $\begin{array}{r}-0.0010 \\
(0.130) \\
\end{array}$ \\
\hline $\mathrm{Y}$ & - & $\begin{array}{r}0.8426 \\
(0.25)\end{array}$ & - & - & - & - & $\begin{array}{r}0.8058 \\
(0.29)\end{array}$ \\
\hline
\end{tabular}


table 2 cont.

\begin{tabular}{|c|c|c|c|c|c|c|c|}
\hline 1 & 2 & 3 & 4 & 5 & 6 & 7 & 8 \\
\hline CONF & - & - & $\begin{array}{r}-0.127 \\
(0.31)\end{array}$ & - & - & - & $\begin{array}{r}-0.0994 \\
(0.46)\end{array}$ \\
\hline MI & - & - & - & $\begin{array}{r}-0.0004 \\
(0.30)\end{array}$ & - & - & $\begin{array}{r}-0.0004 \\
(0.41)\end{array}$ \\
\hline EQ & - & - & - & - & $\begin{array}{r}-0.1509 \\
(0.80) \\
\end{array}$ & - & $\begin{array}{r}-0.4133 \\
(0.54) \\
\end{array}$ \\
\hline TAC & - & - & - & - & - & $\begin{array}{r}-0.0249 \\
(0.62) \\
\end{array}$ & $\begin{array}{r}0.0058 \\
(0.92) \\
\end{array}$ \\
\hline $\mathrm{C}$ & $\begin{array}{r}0.0672 \\
(0.68)\end{array}$ & $\begin{array}{r}0.1378 \\
(0.42)\end{array}$ & $\begin{array}{r}0.1404 \\
(0.43)\end{array}$ & $\begin{array}{r}0.1662 \\
(0.38)\end{array}$ & $\begin{array}{r}0.0752 \\
(0.65)\end{array}$ & $\begin{array}{r}0.1342 \\
(0.53)\end{array}$ & $\begin{array}{l}0.309 \\
(0.59)\end{array}$ \\
\hline McFadden $\mathrm{R}^{2}$ & 0.013 & 0.015 & 0.015 & 0.015 & 0.013 & 0.013 & 0.018 \\
\hline $\begin{array}{l}\text { Actual Correct } \\
\text { Prediction }(\%)\end{array}$ & 57.29 & 57.92 & 54.37 & 54.17 & 57.29 & 58.33 & 54.79 \\
\hline $\begin{array}{l}\text { Expected Correct } \\
\text { Prediction }(\%)\end{array}$ & 51.68 & 51.79 & 51.77 & 51.79 & 51.69 & 51.70 & 51.98 \\
\hline Log likelihood & -324.14 & -323.49 & -323.43 & -323.61 & -324.11 & -324.02 & -328.51 \\
\hline Total Obsn & 480 & 480 & 480 & 480 & 480 & 480 & 480 \\
\hline
\end{tabular}

$* \mathrm{p}<0.01, * * \mathrm{p}<0.05, * * * \mathrm{p}<0.1$.

Source: Authors' own calculation.

Column 2 in Table 2, of all the variables, only economic freedom and trade openness are statistically significant. The coefficient of economic freedom is positive which means that more economic freedom increases the probability of high inflows of external aid in Africa. This also holds in the case of the size of government, but it is not statistically significant. External debt overhang is also positive, as expected, but not statistically different from zero. Unexpectedly, the index of trade openness turns out with a wrong sign; the coefficient is negative and statistically significant. That is, the probability of a high external aid allocation may not increase with an increase in the degree of trade openness in Africa. The estimated negative sign of trade openness is similar to the study of Ali and Isse (2006) that found a negative relationship between external trade and external aid. The role of population density is equally negative but not significant. In column 3 through 9, all the additional alternative variables included are negative and statistically not different from zero except in column 3 where the dummy for the income group is positive but also not significant. In all the columns in Table 2, the sign and the level of significance of economic freedom and the external debt burden remain unchanged even with additional variables. Moreover, a result from the combination of all the variables (reported in column 9) is much consistent with the baseline regression result in column 2. Furthermore, at the bottom of Table 2, the actual percentage of correct prediction in the entire model exceeds the expected percentage of correct prediction. 
For "internal consistency", Table 3 shows the results estimated for sub-regions within Africa - sub-Saharan Africa and North Africa using equation (5) specification contrast to the estimated results for Africa as a whole. The result obtained for sub-Saharan Africa is similar to that of Africa as a whole. The economic freedom and external debt burden are positive among the regions. While the effect of external debt burden is not significant in the three regions, the coefficient of economic freedom is significant for Africa and sub-Saharan Africa. The sign of the coefficient of government size and population density for sub-Saharan Africa and North Africa remain the same as that of Africa. However, trade openness although negative as in the other regions, is not statistically significant for North Africa. The actual percentage of perfect prediction for sub-Saharan Africa is roughly 59\%, and 57\% for North Africa. The difference in the estimates for North Africa compared to sub-Saharan Africa and Africa is likely as a result of the North Africa relative few sample size.

Table 3. Probit regressions on the external aid behavior: comparison among Africa, sub-Saharan Africa and North Africa

\begin{tabular}{|l|r|r|r|}
\hline \multicolumn{1}{|c|}{ Variables } & \multicolumn{1}{|c|}{ Africa } & Sub-Saharan Africa & North Africa \\
\hline \multirow{2}{*}{ EF } & 0.0064 & 0.0072 & 0.065 \\
& $(0.03)^{* *}$ & $(0.02)^{* *}$ & $(0.89)$ \\
\hline \multirow{2}{*}{ EXDH } & 0.0045 & -0.0011 & 0.5103 \\
& $(0.79)$ & $(0.95)$ & $(0.35)$ \\
\hline \multirow{2}{*}{ GZ } & 0.0063 & 0.0033 & 0.1300 \\
& $(0.52)$ & $(0.74)$ & $(0.60)$ \\
\hline \multirow{2}{*}{ TPN } & -0.0046 & -0.0044 & -0.0445 \\
& $(0.01)^{*}$ & $(0.01)^{*}$ & $(0.29)$ \\
\hline \multirow{2}{*}{ POPD } & -0.0005 & -0.0004 & -0.0112 \\
& $(0.32)$ & $(0.46)$ & $(0.72)$ \\
\hline \multirow{2}{*}{ C } & 0.0672 & 0.068 & 0.1197 \\
& $(0.68)$ & $(0.68)$ & $0.99)$ \\
\hline McFadden R & 0.013 & 0.015 & 0.046 \\
\hline Actual Correct Prediction $(\%)$ & 57.29 & 58.86 & 56.67 \\
\hline Expected Correct Prediction $(\%)$ & 51.68 & 52.07 & 53.26 \\
\hline Log likelihood & -324.14 & -295.64 & -19.777 \\
\hline Total Obsn & 480 & 440 & 30 \\
\hline
\end{tabular}

$* \mathrm{p}<0.01, * * \mathrm{p}<0.05, * * * \mathrm{p}<0.1$

Source: Authors' own calculation.

For the whole Africa, similar result (reported in Table 4) was obtained using a dynamic probit model with endogeneity problem controlled. Economic freedom retains a positive and statistically significant coefficient though only at a $10 \%$ level and with no lag. 
Table 4. Dynamic probit regressions on the external aid behavior: comparison among Africa, sub-Saharan Africa and North Africa

\begin{tabular}{|c|c|c|c|c|}
\hline \multirow{2}{*}{ Variables } & \multicolumn{2}{|c|}{ Africa } & \multirow{2}{*}{$\begin{array}{l}\text { Sub-Saharan } \\
\text { Africa }\end{array}$} & \multirow{2}{*}{ North Africa } \\
\hline & (1) & (2) & & \\
\hline $\mathrm{D}(-1)$ & $\begin{array}{l}0.8493 \\
(0.00)^{*}\end{array}$ & $\begin{array}{l}0.8504 \\
(0.00)^{*}\end{array}$ & $\begin{array}{l}0.9798 \\
(0.00)^{*}\end{array}$ & $\begin{array}{r}-0.4387 \\
(0.40)\end{array}$ \\
\hline $\mathrm{D}(-2)$ & $\begin{array}{r}0.2227 \\
(0.13)\end{array}$ & $\begin{array}{r}0.2277 \\
(0.12)\end{array}$ & $\begin{array}{r}0.2324 \\
(0.14)\end{array}$ & - \\
\hline EF & $\begin{array}{r}0.0115 \\
(0.67)\end{array}$ & $\begin{array}{r}0.0057 \\
(0.09)^{* * * *}\end{array}$ & $\begin{array}{c}0.0168 \\
(0.71)\end{array}$ & $\begin{array}{r}-0.1760 \\
(0.76)\end{array}$ \\
\hline $\mathrm{EF}(-1)$ & $\begin{array}{r}-0.0280 \\
(0.51) \\
\end{array}$ & - & - & - \\
\hline EXDH & $\begin{array}{r}0.0058 \\
(0.85) \\
\end{array}$ & $\begin{array}{r}0.0021 \\
(0.91)\end{array}$ & $\begin{array}{r}-0.0073 \\
(0.72) \\
\end{array}$ & $\begin{array}{r}0.5185 \\
(0.35)\end{array}$ \\
\hline EXDH(-1) & $\begin{array}{r}-0.0026 \\
(0.93) \\
\end{array}$ & - & - & - \\
\hline GZ & $\begin{array}{r}0.0050 \\
(0.67) \\
\end{array}$ & $\begin{array}{r}0.0033 \\
(0.77) \\
\end{array}$ & $\begin{array}{r}-0.0021 \\
(0.87) \\
\end{array}$ & $\begin{array}{r}0.1929 \\
(0.50) \\
\end{array}$ \\
\hline TPN & $\begin{array}{r}-0.0056 \\
(0.01)^{*} \\
\end{array}$ & $\begin{array}{r}-0.0053 \\
(0.01)^{*} \\
\end{array}$ & $\begin{array}{l}-0.0050 \\
(0.02)^{* *}\end{array}$ & $\begin{array}{r}-0.0879 \\
(0.09)^{* * * *} \\
\end{array}$ \\
\hline POPD & $\begin{array}{r}-0.0007 \\
(0.26) \\
\end{array}$ & $\begin{array}{r}-0.0006 \\
(0.27) \\
\end{array}$ & $\begin{array}{r}-0.0005 \\
(0.44) \\
\end{array}$ & $\begin{array}{r}-0.0100 \\
(0.77) \\
\end{array}$ \\
\hline $\mathrm{C}$ & $\begin{array}{r}-0.3225 \\
(0.25) \\
\end{array}$ & $\begin{array}{r}-0.4339 \\
(0.03) \\
\end{array}$ & $\begin{array}{r}-0.5474 \\
(0.08) \\
\end{array}$ & $\begin{array}{r}2.7565 \\
(0.77)\end{array}$ \\
\hline McFadden $\mathrm{R}^{2}$ & 0.120 & 0.119 & 0.149 & 0.099 \\
\hline Actual Correct Prediction (\%) & 69.53 & 69.27 & 72.44 & 56.67 \\
\hline Expected Correct Prediction (\%) & 60.02 & 59.98 & 62.54 & 53.26 \\
\hline Log likelihood & -224.53 & -224.76 & -195.77 & -16.715 \\
\hline Total Obsn & 384 & 384 & 352 & 27 \\
\hline
\end{tabular}

$* \mathrm{p}<0.01, * * \mathrm{p}<0.05, * * * \mathrm{p}<0.1$

Source: Authors' own calculation.

Table 5 highlights the results of the model specification for Africa in line with equation (6) and (7). In Table 5, the results in column 2 were estimated with a period effect but left a regional effect uncontrolled. The obtained coefficients are not that different from those in Table 2. That is, the effects of economic freedom and external debt burden are positive which imply that economic freedom and external debt burden have a positive effect on the probability that African countries have higher external aid inflow over the sample period. Nevertheless, the coefficient of external debt burden is statistically not different from zero but that of economic freedom is statistically different from zero. The coefficient of government size is also positive but statistically insignificant. Both trade openness and population density maintain a negative sign, but the population density coefficient is not statistically different from zero. The result in column 3 
controls for regional effect only. This suggests that only economic freedom significantly and positively determines external aid behavior in Africa. External debt burden may not increase the likelihood of more inflow of external aid in Africa. The same holds for the size of government, trade openness and population density. The dummy variable representing the West Africa region is positive and significant but only at $10 \%$. In column 4 of Table 5 , both the period effect and regional effect were controlled in the model. Although the direction of impact of the degree of economic freedom is still positive, the coefficient is significant at $10 \%$ only. The effect of external debt burden is positive and not significant. The government size, population density and trade openness are not statistically significant.

Table 5. Regional and period effects controlled probit regressions on external aid behavior in Africa

\begin{tabular}{|c|c|c|c|}
\hline Variables & $\begin{array}{l}\text { With period effect } \\
\text { only }{ }^{\dagger \dagger}\end{array}$ & $\begin{array}{c}\text { With regional } \\
\text { effect }\end{array}$ & $\begin{array}{c}\text { Both regional and period } \\
\text { effects }^{\dagger \dagger}\end{array}$ \\
\hline EF & $\begin{array}{l}0.0083 \\
(0.01)^{*}\end{array}$ & $\begin{array}{r}0.0077 \\
(0.03)^{* *}\end{array}$ & $\begin{array}{r}0.0100 \\
(0.05)^{* * * *}\end{array}$ \\
\hline EXDH & $\begin{array}{l}0.016 \\
(0.31) \\
\end{array}$ & $\begin{array}{r}0.0018 \\
(0.92) \\
\end{array}$ & $\begin{array}{r}0.0134 \\
(0.41) \\
\end{array}$ \\
\hline GZ & $\begin{array}{r}0.0132 \\
(0.17)\end{array}$ & $\begin{array}{r}0.0049 \\
(0.68)\end{array}$ & $\begin{array}{r}0.0144 \\
(0.23)\end{array}$ \\
\hline TPN & $\begin{array}{r}-0.0059 \\
(0.00)^{*} \\
\end{array}$ & $\begin{array}{l}-0.0040 \\
(0.02)^{* *}\end{array}$ & $\begin{array}{r}-0.0053 \\
(0.00)^{*} \\
\end{array}$ \\
\hline POPD & $\begin{array}{r}-0.0006 \\
(0.21) \\
\end{array}$ & $\begin{array}{r}-0.0007 \\
(0.22) \\
\end{array}$ & $\begin{array}{r}-0.0008 \\
(0.13) \\
\end{array}$ \\
\hline WA & - & $\begin{array}{r}0.0217 \\
(0.09)^{* * * *}\end{array}$ & $\begin{array}{r}0.0095 \\
(0.96)\end{array}$ \\
\hline $\mathrm{NA}$ & - & $\begin{array}{r}0.2782 \\
(0.32) \\
\end{array}$ & $\begin{array}{r}0.240 \\
(0.43) \\
\end{array}$ \\
\hline EA & - & $\begin{array}{r}0.1760 \\
(0.34)\end{array}$ & $\begin{array}{r}0.1391 \\
(0.47)\end{array}$ \\
\hline SA & - & $\begin{array}{r}-0.0067 \\
(0.92)\end{array}$ & $\begin{array}{r}-0.1096 \\
(0.70)\end{array}$ \\
\hline $\mathrm{C}$ & $\begin{array}{r}-0.2204 \\
(0.37)\end{array}$ & $\begin{array}{r}-0.0188 \\
(0.92)\end{array}$ & $\begin{array}{r}0.1668 \\
(0.24)\end{array}$ \\
\hline McFadden $\mathrm{R}^{2}$ & 0.081 & 0.016 & 0.084 \\
\hline Actual Correct Prediction (\%) & 64.79 & 54.58 & 65.00 \\
\hline Expected Correct Prediction (\%) & 56.08 & 51.93 & 56.67 \\
\hline Log likelihood & -301.83 & -323.05 & -300.82 \\
\hline Total Obsn & 480 & 480 & 480 \\
\hline
\end{tabular}

${ }^{\dagger}$ Indicates period effect is not reported, $* \mathrm{p}<0.01, * * \mathrm{p}<0.05, * * * \mathrm{p}<0.1$.

Note: In column 3 and 4, middle Africa is treated as a dummy benchmark variable.

Source: Authors' own calculation. 


\section{Discussion of findings}

Contrary to the previous studies, the main essence of this paper was on estimating and predicting the likelihood of economic freedom and external debt burden determining the behavior of external aid allocation in Africa, one of the largest aid recipient regions globally. The results of the probit regression estimated revealed that the coefficient of economic freedom is positive and statistically significant. Suppose other factors remain unchanged, it implies that if the degree of economic freedom is strengthened, the probability that there would be more allocation of external aid to Africa will increase. Among the possible reasons one may point at is the influence of free-market ideas guiding the operations of some aid donors. External aid donor bodies like USAID, World Bank, IMF and some key US government agencies are known to advocate free market ideas hinged critically on economic freedom and market liberalizations (Todaro \& Smith, 2014). Bodies like IMF, although preferred not to be classified as aid donor even though it grants credits of which repayment may later be pardoned, required, as a condition, the aid recipients countries have a good degree of market freedom to access higher credit service of the body.

Therefore, more external aid may not flow into African countries with lower degree of economic freedom. African countries that are not willing to pursue more degree of economic freedom are therefore highly likely at risk of attracting a low level of external aid. The consequence is likely to be severe for countries that depend predominantly on external aid to solve the country's socioeconomic problems. In the case of external debt burden, it was positive as expected and suggests that the possibility that African countries will receive more aid allocation from aid donors increases with the level of external debt burden. That is, African countries with problem of a high external debt burden are more likely to receive more external aid. The IMF and Paris Club loans forgiveness initiative or debt crisis intervention at different times as in the 1980-1990s and 2000s for many countries in Africa with a high debt burden profile are a good example. Nonetheless, on average, since the coefficient is not statistically different from zero, aid allocations to African countries may not improve with an increase in the level of external debt burden at present.

Furthermore, the probability of getting more external aid in African countries increases with an increase in the size of government based on the results estimated. This is probably as a result of the strong bargaining power and mounting pressure ability of most countries with a large size of government. 
Besides, countries with large government size often have much will for high consumption which favor some aid donors like Japan that usually tie aid-giving to trade particular exportations of their products to their aid beneficiaries. However, since the coefficient of the government size is not statistically significant, a presupposition that external aid increases with an increase in the government size will be costly for African countries. Lastly, it is shocking that higher degree of trade openness and population density reduces the probability of a high level of external aid inflow. This may be as a result of the spill-over effect resulting from a combined differing ideas and policy objectives, priorities or conditions attached to external aid allocation by the donors. However, since the coefficient of the population density is not significant, its negative impact in the model is meaningless.

\section{Conclusions}

The paper contributes to filling the gap in the literature on the possible drivers of external aid inflows in Africa. But, unlike the previous studies that dwell on variables like ethnicity, taxes on international trade, quality of governance, HIV/AIDs and poverty, using a probability model (static and dynamic probit model), the study traced external aid fluctuations in Africa to external debt burden and the extent of restriction imposed on economic freedom in African countries.

Based on a piece of empirical evidence the study found, though a high external debt burden may not increase the odd of getting more external aid, more degree of economic freedom enhances a large inflow of external aid in Africa. Therefore, an improved degree of economic freedom is a good policy instrument to raise the level of external aid inflow in Africa. It therefore means that to make African countries aid-independent, restraining the degree of economic freedom is necessary. However, in making such a decision, an evaluation of the consequence of restraining the level of economic freedom must be done to ascertain the level of risks or costs linking to a lower degree of economic freedom in Africa.

This paper focused on the direct effect of economic freedom and external debt burden to characterize the behavior of external aid inflow in Africa. Nonetheless, owing to the escalating rate of poverty in Africa in recent time, future research should consider extending the analysis to include the interfering role of poverty in the relationship. 


\section{Disclosure statement}

No potential conflict of interest was reported by the author(s).

\section{References}

Adediyan, A. R., \& Obadoni, V. N. (2020). Aid disbursement, disease and school enrolment in sub-Saharan Africa: An empirical evaluation. Kardan Journal of Social Sciences and Humanities, 3(2), 68-85. Retrieved from https://kardan.edu.af/data/public/files/KJSSH3.1-2020-0527072021013930.pdf

Ali, M., Banks, G., \& Parsons, N. (2015). Why donors give aid and to whom? A critique of the historical and contemporary aid allocation regime. Dialoque $X, 2,316-331$. Retrieved from https://www.semanticscholar.org/paper/Why-Donors-Give-Aid-andto-Whom-A-Critique-of-the-Ali-anks/06d4a959083e6749e096c3bbf8a6652e0f117eld

Appiah-Konadu, P., Junior, F. S., Eric, A., \& Twerefou, D. K. (2016). The effect of foreign aid on economic growth in Ghana. African Journal of Economic Review, 4(2), 248-261. https://doi.org/10.22004/ag.econ.264465

Asongu, S. A. (2014). The questionable economics of development assistance in Africa: Hot-fresh evidence, 1996-2010. The Review of Black Political Economy, 41(4), 455-480. https://doi.org/10.1007/s12114-014-9203-0

Alesina, A., \& Dollar, D. (2000). Who gives foreign aid to whom and why? Journal of Economic Growth, 5, 33-64. https://doi.org/10.1023/A:1009874203400

Ali, A. M., \& Isse, H. S. (2006). An empirical analysis of the determinant of foreign aid: A panel approach. International Advances in Economic Research, 12, 241-250. https://doi.org/10.1007/s11294-006-9016-4

Asteriou, D., \& Hall, S. (2011). Applied econometrics (2nd ed.). New York: Palgrave Macmillan.

Burnside, C., \& David, D. (2000). Aid, policies, and growth. American Economic Review, 90(4), 847-868. https://doi.org/10.1257/aer.90.4.847

Clemens, M. A., Radelet, S., Bhavnani, R. R., \& Bazzi, S. (2012). Counting chickens when they hatch: Timing and the effects of aid on growth. The Economic Journal, 122(561), 590-617. https://doi.org/10.1111/j.1468-0297.2011.02482.x

Dalgaard, C.-J., \& Hansen, H. (2001). On aid, growth and good policies. Journal of Development Studies, 37(6), 17-41. https://doi.org/10.1080/713601081

Easterly, W. (2003). Can foreign aid buy growth? Journal of Economic Perspectives, 7(3), 23-48. https://doi.org/10.1257/089533003769204344

Eregha, P. B. (2009). Foreign aid growth and determinants in Nigeria: An autoregressive framework. Pakistan Journal of Social Sciences, 6, 309-312. Retrieved from https://docsdrive.com/pdfs/medwelljournals/pjssci/2009/309-312.pdf 
Fleck, R. K., \& Christopher, K. (2010). Changing aid regimes? U.S. Foreign Aid from the Cold War to the war on terror. Journal of Development Economics, 91(2), 185-197. https://doi.org/10.1016/j.jdeveco.2009.09.011

Flink, G., \& Radaelli, S. (2009). Determinants of international emergency aid: Humanitarian need only? (Policy Research Working Paper, No. 4839). Washington, DC: The World Bank. Retrieved from https://openknowledge.worldbank.org/bitstream/handle/10986/4035/WPS4839.pdf? sequence $=1 \&$ is Allowed $=\mathrm{y}$

Furuoka, F. (2017). Determinants of China's and Japan's foreign aid allocations in Africa. African Development Review, 29(3), https://doi.org/10.1111/1467-8268.12275

Iyoha, M. (2004). Macroeconomics: Theory and policy. Benin City: Mindex Publishing.

Jayathilaka, R., \& Bandara, R. (2009). Effectiveness of foreign aid: A critical assessment. Sri Lanka Economic Journal, 9(2), 53-78

Kaya, I., \& Kaya, O. (2020). Foreign aid, institutional quality and government fiscal behaviour in emerging economies: An empirical investigation. The Quarterly Review of Economics and Finance, 76, 59-67.

https://doi.org/10.1016/j.qref.2019.08.004

Kaya, O., Kaya, I., \& Gunter, L. (2012). Development aid to agriculture and economic growth. Review of Development Economics, 16(2), 230-242. https://doi.org/10.1111/j.1467-9361.2012.00658.x

Kim, E. M., \& Oh, J. (2012). Determinants of foreign aid: The case of South Korea. Journal of East Asian Studies, 12(2), 251-273. https://www.jstor.org/stable/23418809

Liu, X., Fan, H., Chao, C.-C., \& Yu, E. S. H. (2019). Foreign aid, human capital acquisition and educated unemployment: Fish or fishing. International Review of Economics and Finance, 64, 1-8. https://doi.org/10.1016/j.iref.2019.05.007

Moyo, D. (2009, March 21). Why external aid is hurting Africa. The Wall Street Journal. Retrieved from https://www.wsj.com/articles/SB123758895999200083.

Park, J. D. (2019). Assessing the role of foreign trade, donors and recipients. In J.-D. Park, Re-inventing Africa's development (pp. 37-60). Cham: Palgrave Macmillan. Retrieved from https://link.springer.com/content/pdf/10.1007\%2F9783-030-03946-2.pdf.\%20https:/doi.org/10.1007/978-3-030-03946-2

Rena, R. (2013). Is foreign aid panacea for African problems? The case of Namibia. Managing Global Transitions, 11(3), 223-241. Retrieved from https://www.fmkp.si/zalozba/ISSN/1581-6311/11_223-241.pdf

Sun, Y. (2020, April 20). China and Africa's debt: Yes to relief, no to blanket forgiveness. Africa in Focus. Retrieved from

https://www.brookings.edu/blog/africa-in-focus/2020/04/20/china-and-africas-debtyes-to-relief-no-to-blanket-forgiveness/

Todaro, M. P., \& Smith, C. S. (2014). Economic development (12 ${ }^{\text {th }}$ ed.). New York: Addison-Wesley. 
Tseggai, I. (2006, March 22). Foreign aid: A poison pill or a panacea for progress (Paper presentation). International Studies Association Meeting, San Diego, CA, United States.

United Nations. (2006). Doubling aid: Making the "Big Push" work. Economic Development in Africa. New York and Geneva: Author. Retrieved from https://unctad.org/system/files/official-document/gdsafrica20061_en.pdf

Uzonyi, G., \& Rider, T. (2017). Determinants of foreign aid: Rivalry and domestic instability. Empirical and Theoretical Research in Internal Relations, 43(2), 272-299. https://doi.org/10.1080/03050629.2016.1171763

Wooldridge, J. M. (2013). Introductory econometrics: A modern approach (5th ed.) Boston, MA.: South-Western, Cengage Learning.

Zengin, H., \& Korkmaz, A. (2019). Determinants of Turkish's foreign aid behaviour. New Perspectives on Turkish, 60, 109-135. https://doi.org/10.1017/npt.2019.1

Zhang, G. (2004). The determinants of foreign aid allocation across China: The case of World Bank loans. Asian Survey, 44(5), 691-710.

https://doi.org/10.1525/as.2004.44.5.691 